Meta

Journal des traducteurs

Translators' Journal

\title{
Growing a Project-Based Translation Pedagogy: A Fractal Perspective
}

\section{Don Kiraly}

Volume 57, numéro 1, mars 2012

La CIUTI, chef de file pour la promotion de l'employabilité et de la recherche

CIUTI: Leader in Advocating Employability and Research

URI : https://id.erudit.org/iderudit/1012742ar

DOI : https://doi.org/10.7202/1012742ar

Aller au sommaire du numéro

Éditeur(s)

Les Presses de l’Université de Montréal

ISSN

0026-0452 (imprimé)

1492-1421 (numérique)

Découvrir la revue

Citer cet article

Kiraly, D. (2012). Growing a Project-Based Translation Pedagogy: A Fractal

Perspective. Meta, 57(1), 82-95. https://doi.org/10.7202/1012742ar
Résumé de l'article

Le présent article propose un cheminement fractal à travers la psychologie et la philosophie éducative, avec l'intention de faire la lumière sur une représentation arborescente de sources d'inspiration interdisciplinaires et complémentaires pour une pédagogie de la traduction par projets.

Commençant par la méthode d'apprentissage socioconstructiviste proposée au tournant du millénaire, notre propos tente de brosser un vaste portrait des influences synergiques sous-jacentes à l'approche émergente « holistique-expérientielle » de la formation en traduction. Le post-modernisme, l'énaction dans les sciences cognitives, la théorie de la complexité, la théorie éducative transformationnelle et l'épistémologie socioconstructiviste sont quelques-unes des racines complémentaires pouvant inspirer et fonder une approche centrée sur l'apprenant visant à développer l'expertise traductionnelle à l'université.
Ce document est protégé par la loi sur le droit d'auteur. L'utilisation des services d’Érudit (y compris la reproduction) est assujettie à sa politique d'utilisation que vous pouvez consulter en ligne.

https://apropos.erudit.org/fr/usagers/politique-dutilisation/ 


\title{
Growing a Project-Based Translation Pedagogy: A Fractal Perspective
}

\author{
DON KIRALY \\ Johannes Gutenberg-Universität Mainz, Germersheim, Germany \\ don.kiraly@gmx.de
}

\begin{abstract}
RÉSUMÉ
Le présent article propose un cheminement fractal à travers la psychologie et la philosophie éducative, avec l'intention de faire la lumière sur une représentation arborescente de sources d'inspiration interdisciplinaires et complémentaires pour une pédagogie de la traduction par projets. Commençant par la méthode d'apprentissage socioconstructiviste proposée au tournant du millénaire, notre propos tente de brosser un vaste portrait des influences synergiques sous-jacentes à l'approche émergente «holistique-expérientielle» de la formation en traduction. Le post-modernisme, l'énaction dans les sciences cognitives, la théorie de la complexité, la théorie éducative transformationnelle et l'épistémologie socioconstructiviste sont quelques-unes des racines complémentaires pouvant inspirer et fonder une approche centrée sur l'apprenant visant à développer l'expertise traductionnelle à l'université.
\end{abstract}

\begin{abstract}
This article traces a fractal path through educational psychology and philosophy in an attempt to elucidate an arborescent perspective of complementary inter-disciplinary sources of inspiration for a project-based translation pedagogy. Starting with a socialconstructivist, project-based approach proposed at the turn of the millennium, an attempt is made to paint a broader picture of the synergistic influences underlying an emerging "holistic-experiential" approach to translator education. Post modernism, enactive cognitive science, complexity theory, transformational educational theory and social-constructivist epistemology are some of the complementary roots that can be seen as potential sources of inspiration to nourish a learning-centered approach to developing translator expertise in institutional settings.
\end{abstract}

\section{MOTS-CLÉS/KEYWORDS}

apprentissage holistique-expérientiel, apprentissage par projets, représentation fractale, énaction, interdisciplinarité

holistic-experiential learning, project-based learning, fractal representation, enaction, interdisciplinarity

\section{Beyond Social-Constructivism}

Over a decade has now gone by since my monograph entitled A Social Constructivist Approach to Translator Education (Kiraly 2000) was published. Back then, "projectbased learning" was quite new to translation pedagogy and I was able to cite only two researchers, Rosemary Mackenzie and Jean Vienne, who were publishing on the topic at the time. At the School of Applied Linguistics and Cultural Studies of the University of Mainz (already then the largest translator education institution in the world), where I have been educating translators since 1983, there was to my 
knowledge not a single colleague in any department who was experimenting with project-based learning in the year 2000.

Ten years later, in the winter semester of 2010-2011, a lecture series was held at the School with the title Project-based Translator Education. Over the course of the semester, 16 lectures were held, each one of them dealing with a different project that had recently been completed or that was still underway within the translator or interpreter training programs in Germersheim. The Zeitgeist in translator education has indeed changed within a decade. The lecture series in Germersheim is just one sign of a distinct movement in professional translator education programs away from an almost exclusive focus on contrived, teacher-centered, transmissionist teaching towards experiential, collaborative learning.

And yet, while listening to the series of lectures in question and then, while coediting the articles that would be included in a book on the overall topic of project work in translation and interpreting studies, I was left with considerable uncertainty regarding many of the presenters' educational philosophies and their basic assumptions about the nature of knowledge, and about how the various pedagogical experiments under review were related to other research in translation pedagogy and beyond. To situate the various approaches underlying the experiments, I would have needed to know more, for example, about the presenters' educational epistemologies, their understandings of how the mind works, how teams function and how learning occurs, as well as their views on the nature of translation processes themselves. In the case of many of the lectures, there seemed to be an implicit assumption that the educational translation "project" has an intrinsic value that requires hardly any explanation or justification. While projects may well be intuitively inviting for teachers and students tired of transmissionist approaches to learning translation skills, I would argue that providing insight into one's underlying pedagogical epistemology and the network of links to related inter-disciplinary thought and research not only can contribute considerable credibility to a project-based pedagogical approach, but can also help ensure its consistency, coherence and cogency.

Here I will touch upon a few of the key links between, on the one hand, my own project-based approach to translator education, published in Kiraly (2000) and theories and research in a number of disciplines that have contributed to the evolution of this approach over the past decade on the other. Various aspects of this interwoven organic system of links and roots have been discussed in a series of recent publications (Kiraly 2005; 2006a; 2006b; 2008; 2009; 2010) but I will attempt to bring the most prominent ones together in a concerted manner here. I have two main objectives in mind. I would like to illustrate on the basis of my approach that the explicitation of the epistemological and (multi-) disciplinary roots of a pedagogy can contribute significantly to its credibility and viability beyond a particular classroom or curriculum.

\subsection{The Social-Constructivist Approach to Translator Education in a Nutshell}

My project-based approach to translator education was originally focused primarily on the Vygotskian social-constructivist view that learning and cognitive development evolve first and foremost through communication between people and that thinking within the mind of an individual person is a second-order derivative of collective 
thinking and participation in social interaction. I drew initially on various constructivisms, including those of Lev Vygotsky (1994), and John Dewey (1938), work on collaborative learning in communities of practice, for example by Kenneth Bruffee (1995), and expertise studies, including the research of Donald Schon (1987), and Carl Bereiter and Marlene Scardamaglia (1993). On the basis of these and related sources, I outlined a systematic approach to curriculum development, course and lesson planning, classroom interaction, computer-based tool training and learning assessment revolving around the key educational event of the "authentic, collaborative translation project" (a holistic piece of work undertaken by a team of students in the service of a real-world client or user).

Rather than taking a conventional reductionist approach to translation skills or competences and contrastive translation problems, my personal non-foundational pedagogical epistemology led me to propose the authentic project as the key activity in the educational process, with the students' main focus being on tackling, experiencing and learning about the translator's profession through the real work at hand in the classroom. It would be through involvement in this authentic work experience that students would be developing the skills and competences that would prepare them to tackle new projects of ever-increasing difficulty within and eventually outside the academic setting. I proposed, too, that translator education could be seen as a sequence of complex projects, which, (borrowing from the perspective of complexity theory), instead of extending in building-block fashion in a linear, Euclidean flowchart-like sequence from simple to complicated or from basic knowledge to advanced skills, flow and emerge in a recursive process of ever-increasing autonomy and competence.

By undertaking a series of complex collaborative projects - the completion of each one ushering in the start of the next - students would be exposed to a broad sample of authentically situated and multi-facetted learning activities in real (and not just realistic) working environments. These would serve as the venues for initiating and pursuing the development of translator sub-competences through first-hand experience, with the support of peers (project team-members) and the universityassigned "instructor" (functioning more as a guide, assistant, resource person and mentor than a teacher) as well as the input and feedback of clients, proofreaders and editors.

I like to compare the situation in this type of classroom work to that of a prospective tightrope walker who might conceivably start out by walking a learner's rope just a few inches above the floor, but who at some point must climb up high in the air to make their way across the abyss on a narrow rope swaying far above the floor - long before they venture out under a crowded big top. The translation student, in my view, should have plenty of opportunities to actively, viscerally and collaboratively experience the challenges, quandaries and pressures, and the often contradictory allegiances and unexpected pitfalls to which translators are subjected - during their studies and not only after their completion. This is embodied cognition, an essential feature of professional education. I have described the overall goal of my approach as the empowerment of students. Rather than perpetuate the conventional role of the educational institution to mold, regulate and control learner's behavior by distributing knowledge to them, the goal is to empower them to take responsibility for their own learning, their own sense-making and their own futures. My original approach can be described as transformationist, collaborative, experiential, and learning- 
centered rather than transmissionist, solitary, contrived and teaching-oriented like the teacher-centered chalk-and-talk technique that is still pervasive in far too many conventional translation classes, as emphasized by Echeverri (2008).

In the next section, I would like to show how this approach is deeply eclectic. By this I mean that the conceptual roots of the approach, drawn from a number of different domains, serve as a pedagogy-cultivation system that can inform the approach at every level, from the development of an entire translator education curriculum down to the specific activities undertaken in a particular class. I also wish to illustrate how my approach is evolving due to the influence of new theoretical influences from the outside as well as my new understandings of pedagogical processes gained through the very implementation of the approach itself.

\section{On Pedagogical Networks: Synergies, Roots and Branches}

In what I see as a fractal ${ }^{1}$ depiction of translator education methodology, I have presented in Figure 1 an arboreal outline of some of the potential conceptual and epistemological roots and links that can be seen to underlie my current approach to curriculum development and course design. The tree is meant to metaphorically reflect the fractal nature of theory-based practice. I would like to emphasize the importance of adopting a metaphorical explanation here because, along with Lakoff and Johnson (1980) I strongly believe that the metaphors we use to talk about our social reality actually help us construe and, in fact, construct that reality:

Metaphors may create realities for us, especially social realities. A metaphor may thus be a guide for future action. Such actions will, of course, fit the metaphor. This will, in turn, reinforce the power of the metaphor to make experience coherent. In this sense metaphors can be self-fulfilling prophecies. (Lakoff and Johnson 1980: 112)

I have found that focusing on the fractal metaphor while designing a course, preparing or teaching a class and developing or grading a test serves as a constant tangible reminder of my roles and responsibilities as an educator from a post-modernist perspective. My depiction of this arboreal model is meant to be illustrative of the relationships involved but is not intended to be exhaustive, exclusive or precise. ${ }^{2}$

If I had to identify a key term that summarizes my approach today, it would be holistic-experiential, emphasizing the proactive role of learners in coming to know through (inter-)personal experience. A step back from a purely social-constructivist view reveals a wide range of approaches in a variety of disciplines that support, nourish and inspire this approach. The choice of a living tree to illustrate the relationship between these multi-disciplinary roots and my holistic-experiential approach reflects the ecological view that learning is a synergistic inter-subjective process. Similarly, the synergistic relationship between roots and leaves metaphorically reflects the belief that findings of pedagogical research in translation studies can inform as well as be informed by supporting disciplines. 
FIGURE 1

A fractal view of potential multi-disciplinary links in project-based translation pedagogy

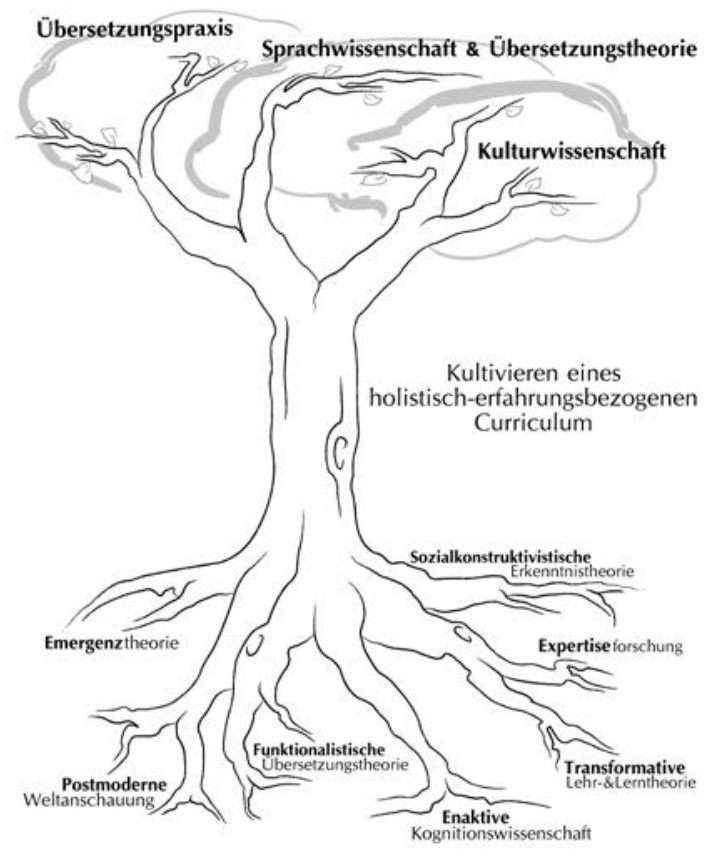

I suggest that the network of roots underlying any pedagogical approach must be identifiable and synergistic if the latter is to be compelling. In other words, the pedagogical praxis that represents the implementation and manifestations of an approach, from curriculum design to course creation to pedagogical techniques and evaluation, must be consistent with the underlying conceptual roots if it is to be considered to reflect a well-founded, viable system. If not, I contend, it may still be superficially cohesive and plausible but, like a plant that has been severed from its root system, its capability for sustaining itself will be severely limited.

\subsection{Translation as a Complex Process}

If, with over a decade of hindsight, I take a step back from my collaborative, socialconstructivist and authentic-project-based approach to the development of translator competence, I believe we can see it as a natural outgrowth of a particular set of symbiotic and synergistic trends in philosophy and science; I have labeled the roots of my arboreal figure with a set of specific academic disciplines and trends within them that are closely linked to my approach. I see the approach today as a clear manifestation of a complexivist, post-modern worldview - one that has become considerably more explicit in my own mind over the last few years. To explain it simply using common images from complexity theory, I believe that the translator's work is rarely either simple or complicated. Instead, as a rule, it is the epitome of complexity: non-rule-based, self-similar, and recursive. Rarely do we have one-to-one equivalences that we plug mechanically into texts to replace even source language words - much less phrases, clauses, sentences - or sense. And as my own think-aloud 
study of cognitive translation processes, published in Kiraly (1995), showed, rarely are problems solved by mechanical application of rules. As translators constantly face new (albeit self-similar) problems and challenges, adaptable heuristics are far more useful for their work than rigidly applied rules.

Translation is also complex in the sense that we are constantly attempting to solve problems which arise dynamically from the infinitely variable new constellations of words, concepts, messages, authors, clients, translation briefs, collaborators, resources, readers and of course the myriad translator-specific factors that characterize the everyday world of the translator's professional activities. A key focus of functional translation theory is that of specifying the translator's role as that of identifying, assessing and weighing the numerous factors, parameters and constraints of translation tasks and producing target texts that fulfill clients' and readers' needs. And yet there is self-similarity between real-world translation projects; they tend to share categories of features, so that once translators have worked on a large number of projects, they will know that (and in what ways) terminology and knowledge research management, translation norms and professional etiquette are part and parcel of the translator's job - and they will know how to deal with them heuristically by analogy with previously completed projects. The same holds true for translation problems. To solve the myriad new hurdles we face day-by-day and moment-by-moment while working on a translation, (in lieu of translation rules, which rarely, if ever, exist), we depend on our grasp of prior real experience in the world: as translators of course, but also as communicators, team members, information seekers and managers, and computer users. We bring our acquired grasp of norms and strategies to bear on the context at hand in our attempts to deal with the twists and turns of each translation project we are involved in - and every translation problem we encounter (or create).

\section{From the Complexities of Translation to an Enactivist View of Translator Education}

Taking such a view of the translator's work leads us through the arboreal model to a similar view of suitable methods and techniques for translator education. If translator competence entails the ability to construct and apply complex heuristics in tune with relevant communities of practice, then the modernist, mechanistic view of the world that has been passed down to social sciences through the work of such thinkers as René Descartes and Sir Francis Bacon, who in turn drew on pre-modernists like Socrates, Plato, Euclid and Copernicus (see Davis 2004), portraying the world as machine-like - well-ordered and with predictable, rule-based causes and effects - is not a particularly viable basis for a systematic approach to translator education. Instead, from this fractal perspective, my collaborative, authentic-project-based approach can be seen to emerge from situating the need to educate translators within the interplay of synergies between post-modern cosmology and enactivist cognitive science. From this perspective, mind is not considered to be a mechanical storage space or a computer-like problem-solving device located solely within individual brains, but a dynamic, irreproducible process both within and between interlocutors and often partially outsourced to resources in the environment and shared within communities of practice. In this view, translators are not trained, they emerge. In fact, they co-emerge with their fellow learners, their teachers, the institutions they 
attend and the entire community of translation practice with which and whom they interact as they gradually become professional language mediators.

\subsection{The Potential of a Fractal View of Translation Pedagogy}

FIGURE 2

A leaf, a cross-section of a romanesco, and a pattern left by water caught between layers of stone

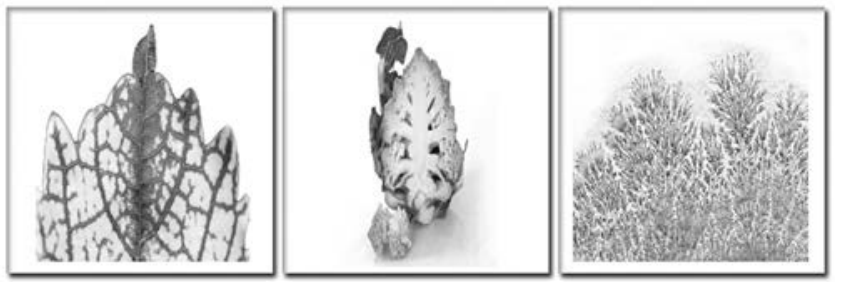

It was the work of Brent Davis (2004), a professor of mathematics education at the University of Calgary, that brought my attention to the potential of a fractal view of educational phenomena for bringing innovation to translator education and also to the potential value of seeing the development of translator competence as an enactive process. In discussions of fractals, the romanesco broccoli (Figure 2) is often cited as a superb example of self-similar complexity in nature. The distinctive pattern of bumps and swirls, of hills and valleys remains virtually identical at different levels of magnification - whether one views the vegetable as a whole from a distance or zooms in closer to focus on a larger protrusion or even a smaller one. The characteristic of self-similarity can be seen in a great variety of natural phenomena, from the branches and roots of plants and trees to the shape of a snowflake, and from the topography of a mountain range to a craggy coastline, and on to the structure of the human vascular and nervous systems - as well as a large number of plants and trees. Fractal geometricians emphasize that such self-similar structures are commonplace in nature - unlike the perfect Euclidean forms that children learn about in school - and that we often utilize to impose rigid order on both artifacts and human activity. In educational and other social settings, interaction has often found to be fractal as well - for example, when knowledge is generated, construed and constructed by individuals, small groups and then larger groups and by an entire community (see Prechter 2004).

The collaborative undertaking of authentic translation projects in an institutional setting can be seen as self-similar to the work done by individual professional translators and teams of translators across the entire translating community of practice. To the extent that educational projects are authentic and the boundaries of the classroom are permeable, the norms of the community will be reflected in each part of every project as well as in the work of each emerging translator. This illustrates the fractal nature of authentic classroom projects and at the same time reflects a social-constructivist view of learning. One aspect that the latter may fail to acknowledge, however, is that learning is not a one-way street. The norms, strategies and procedures utilized by related communities of practice can also be affected by the praxis of each emerging translator. 
This was brought home to me during a subtitling class in which the group took on the job of subtitling a documentary for a small film studio in Wiesbaden. We were instructed to subtitle the film using a generic freeware subtitling program and to save our subtitles in a particular format which an employee at the film studio would import into their professional subtitling equipment for burning onto the film. Neither the students nor I knew anything about the norms and standards of subtitling and we did not know how to use the free software. This knowledge and skill we were, however, able to acquire through self-instruction, which we did. Once we had completed the subtitles some weeks later, we sent them off to the film studio, quite satisfied with our learning experience and the quality of the finished subtitles. Within a day or two we heard back from the film studio: they were unable to import our subtitles into their complex Macintosh system. The deadline was approaching for submitting the subtitled film for inclusion in a film festival and the film studio asked the class to propose a solution to the problem. In the end, the students agreed to travel to Wiesbaden in pairs over a five-day period and to manually enter the subtitles into the studio's Macintosh system.

Of course, the students would have to learn how to use the system themselves and then perform the task at hand under considerable time pressure, which they fortunately managed to do. As it turned out, there was actually no one at the film studio who really knew how to use the company's new Macintosh software, so the students wound up not only learning how to use the software and entering the subtitles into it, but they also taught the personnel of the film studio how to handle the software. The learning on the part of the students, myself and employees of the film studio was multi-facetted and multi-dimensional and perhaps most significantly unplannable and unpredictable.

From this perspective, the individual does not merely find him or herself "situated" in the conventional sense of the term, that is, inserted into an essentially fixed, static situation like an actor placed in a stage setting; instead, the individual is an organic and inextricable part of the situation itself, with each situation itself being situated in ever more complex situations. Here we can see the process of coming to know as occurring concurrently on many planes and in many constellations. Clearly, a transmissionist "conduit" model of learning is hardly applicable here. It may well be the case that teachers can in some sense "transmit" relatively trivial (but no less useful!) knowledge to learners, but from an enactivist perspective, higher-order knowing as "doing, being and becoming" derives especially from authentic personal and collaborative experience.

That is, learning is not seen as a "taking in" or a "theorizing about" a reality that is external to and separate from the learner. Rather, learning is coming to be understood as a participation in the world, a co-evolution of knower and known that transforms both. (Davis, Sumara and Luce-Kapler 2000: 64)

Here, learning is meant to be a highly interactive, proactive and transformative process. It is understood to proceed at different paces and to reveal different contours at each moment and in each individual. The goal is to contribute to the emergence of independent thinkers, competent heuristic problem-solvers and knowledgeable translators who emerge from their studies as neo-professionals with a deep knowledge of the panoply of skills and competences they can expect to encounter in the world beyond the ivory tower. 


\subsection{Further Strands of a Holistic-Experiential Approach}

This way of looking at professional translator education is reflected in the work of cognitive biologists like Humberto Maturana and Francisco Varela (1992) who have shown that natural systems in general, including the human mind, are essentially autopoietic - that is, self-creating and self-sustaining. It was Varela who termed this perpetual process of becoming: "enaction." In this view, learning is not essentially a process of either taking in or constructing information or knowledge, but a perpetual act of becoming. Enaction is very much in line with ecological perspectives, like those initiated by Fritjof Capra and Gregory Bateson, which for decades have focused on the co-emergent, synergistic nature of systems - with radical implications for understanding a tremendous variety of perplexing phenomena in our world, from global warming to classroom interaction.

Other influences on my approach from the areas of educational psychology and philosophy have for many years proven invaluable for informing educational approaches but have rarely been referenced in works on translator education. In the field of foreign-language education, for example, learner-centered instruction (see Tudor 1992) and the humanistic psychology of Carl Rogers and Abraham Maslow have played an important role in moving the focus in some foreign language classrooms away from the arbitrary authority of the teacher and the transmissionist approach to teaching and learning towards the creation of an authentic community in the classroom where learners' psychological needs including affective security, self-esteem and self-actualization can be met through authentic participation in communities of (linguistic, cultural, social and cognitive) practice. I mention these fields of inquiry to further illustrate the potential breadth and depth of the conceptual root system underpinning a pedagogical approach. As I suggested at the beginning of this chapter, I would claim that the synergistic strength of this underlying root system is key to ensuring its viability and sustainability.

\section{Growing a Curriculum}

Now moving on to another fractal level of the holistic-experiential approach I have been "growing," let us look for a moment at curriculum development. Figure 3 is a very basic diagrammatic sketch of how one might view curriculum development from a project-based pedagogical approach based on an emergent world view.

FIGURE 3

Emergent curriculum design in a holistic-experiential approach

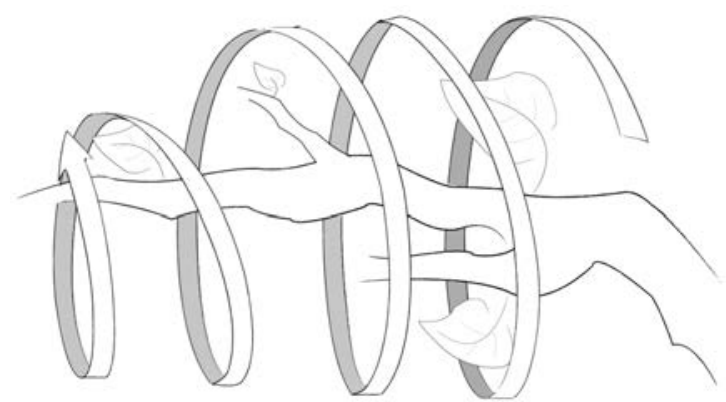


In Figure 2, the crown of my pedagogical development tree (translation praxis, linguistics and translation theory, and cultural studies) comprises three plausible macro-components of translator education curricula. Background (declarative) knowledge is the focus of the latter two components while enacted (procedural) translator competence is the main focus of the translation praxis component. While authentic project work is well-suited as a learning activity for all three components, my focus here is on the translation praxis component.

The basic units of curriculum and course design here are authentic collaborative projects (depicted by the leaves on the branch), each one a scaffolded opportunity for multi-facetted (and co-emergent) experiential learning. Projects again are seen as self-similar and recursive - yet unique, just like coastlines, trees, neuronal networks, and romanesco cauliflowers. The naturally recursive nature of projects is reflected in the spiral feature of the curriulum, which is reminiscent of the concept of the spiral curriculum proposed by Jerome Bruner (1960). By being involved in the selection, organisation and implementation of one new project after another, learners will have a series of authentic, complex opportunities to apply and hone their emerging professional skills. In each project, students are engaged in many facets of the actual work of translators. Of course, projects can and must be selected to cover a wide range of competences that students are likely to need and the kinds of problems they are likely to encounter in the professional world. The sub-competences of translator competence, for example as proposed by the PACTE research group (see Hurtado Albir 2008) could serve as themes for course descriptions and consequently project-work domains. In any event, from an enactivist (and empowering) perspective, it is essential for learners to participate actively in the selection process and in the process of initiating, developing and administering the projects undertaken.

This type of curriculum development process reflects the understanding that learning, the translator's self-concept and the working environment co-emerge simultaneously through collaborative learning activities. From this perspective, the systems represented by the individual and his or her context are inseparably intertwined, and cognition hence occurs in the interstices of mutually-emerging systems. In this view, people are themselves comprised of biological, psychological and neurological systems and are intricately interconnected with the social and physical systems in which they (inter)act. Learning in such an environment is eminently enactivist from a cognitivist science perspective. That is, it is deeply rooted in authentic, embodied action - in situated cognition.

In my view, and as supported by Fenwick and Tennent (2004), while a whole panoply of learning activities - even teacher-designed ones - can be integrated into a holistic-experiential pedagogy, it is the enactivist perspective that provides the broadest, most basic and most plausible epistemological backdrop for the interplay of a variety of pedagogical techniques. My preferred technique for enactive instructional design in translator education (Figure 4) entails initiating authentic learning experiences focused on the collaborative completion of real pieces of work. This can include translations commissioned by real-world clients, but also other types of published work. Groups of my students and I have sought out NGOs needing translations that they could not pay for; students in some of my seminars have contributed to parts of our webpages on Innovation in Translator Education ${ }^{3}$ and other groups of students have then translated those pages into different languages. This book on 
project work in translator education was partially edited within a graduate seminar offered in the English Department at our school.

FIGURE 4

A holistic-experiential translator education classroom

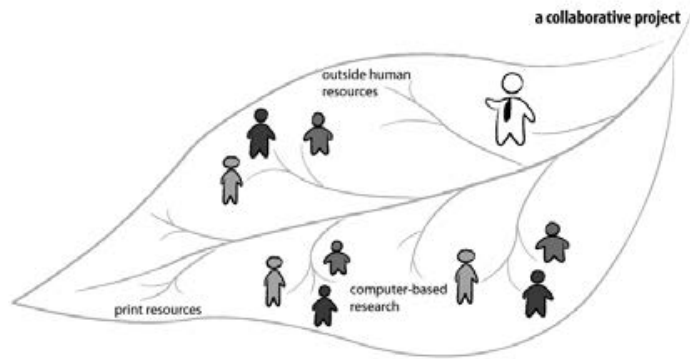

The range of courses I have conducted in this way has varied with departmental assignments for covering curriculum modules each semester, but has included translation practice classes, subtitling courses, an introduction to translation studies and a variety of seminars on second language acquisition and translation studies topics. For each course, starting from a holistic consideration of the job at hand, my groups of students have worked together to identify their own difficulties and the skills they have needed to acquire to get the respective job done, to arrange and manage the division and sequence of labor, to undertake, edit and revise the translation itself and to review and reflect on the completed job. Each project has involved significant, complex interaction with the respective client, extensive research into a specific topic and text-type, the acquisition of technical skills and the need for each participant to assume considerable responsibility for his or her own work. Learning from this perspective is neither structured by the teacher nor predictable. It is emergent: selforganising, self-maintaining, recursive and symbiotic.

Perhaps the most controversial aspect of emergent learning is the chaos it entails. Teaching has long been based on the teacher being in charge, on the teacher's implementation of the curriculum and designing of the syllabus, the teacher's being in control of every moment of every activity in every class. An authentic-project-based class is a different world where chaos reigns - at least initially. This chaos, the bane of the controlling modernist teacher, is the welcome and in fact essential ingredient for learning to deal with complexity. The themes of courses and individual projects, and the efforts of the instructor to guide and assist learners in the creation of specialised competence serve to scaffold the learning process against the backdrop of the chaos in the classroom.

Instead of choosing or designing activities to piece together into lesson plans, I as the instructor attempt to play an optimally invasive, facilitating, guiding and scaffolding ${ }^{4}$ role instead. The less experience a particular group of students has with autonomous collaborative learning, the more I must lay out the groundwork for them: identifying skills and competences they can expect to need in undertaking similar work in professional life, creating a framework for selecting or creating projects, guiding learners into and through teamwork experiences, and helping them assess their ongoing learning success. In courses where students have already acquired a 
significant sense of learner autonomy, have become competent at working efficiently, productively and responsibly in teams, and have learned to assume responsibility for their own learning, my interventions become increasingly minimally invasive, to allow students to move towards ever-greater autonomy as life-long learners as they approach the formal end of their studies. My more extensive scaffolding (and perhaps more frequent use of transmissionist and cooperative activities in class) can be seen as a sort of "assisted bootstrapping," whereby learners are gradually re-empowered to assume responsibility for their own learning. As Hanna Risku has put it:

Along with autonomy, responsibility and emotional involvement emerge motivation and eventually the willingness to initiate action instead of merely completing assigned tasks. (Risku 1998: 114; translated by the author)

In every project course, the students and I first work together to plan the group's overall structure. I attempt to draw the students into every aspect of the (complex) planning process. We co-design the project management process, choose the work that the students wish and need to complete, and determine fair ways in which the students' learning will be assessed. As the project work begins, questions begin to arise along with the need for skills and competences that the students themselves discover they do not yet possess. We then work together to identify and learn about tools, strategies and procedures for resolving the problems that have arisen. It is hence the appearance of problems themselves that frame and specify the learning that students need to undertake and the competences that they need to hone. As Duffy (2009) has pointed out, it is the students' perceived need for new knowledge that is key to acquiring (or constructing) it and not some set of requirements imposed by the teacher.

\section{Conclusion}

My objective in writing this chapter has been to explain the fractal relationships underlying my project-based approach to translator education, which I originally saw as essentially rooted in social-constructivism and that has since evolved clearly into a far more comprehensively holistic-experiential approach with a complex system of inter-disciplinary roots. At the same time, it is clear that much work is yet to be done to establish the viability of the approach beyond the scope of my own classes. For example, team-learning processes that have led to successful project work need to be observed and described to show how and why the approach works. Systematic surveys of student attitudes regarding their emerging competence and self-confidence as semi-professional translators and as increasingly experienced team members would also contribute significantly to our understanding of the value of this approach. I hope that this discussion will contribute to a reassessment of existing and emerging pedagogical approaches with a view toward improving their coherence, consistency and cogency.

\section{NOTES}

1. A fractal is a geometrical shape that appears similar at different levels of magnification. This is the type of recurrent, self-similar pattern that appears often in nature, for example in the branching structure of trees, roots and leaves, the nervous and circulatory systems, natural waterways, coastlines... and romanesco cauliflowers. 
2. Rather than present these synergistic roots of my approach in a rigid manner, I have attempted to weave them directly into the text. The corresponding terms are underlined.

3. Visited on 8 August 2011, <www.ftsk.uni-mainz.de/user/kiraly>.

4. This term was introduced by Wood, Bruner and Ross (1976) to describe the role of teachers in supporting the structuring of learning by individuals. Jerome Bruner later identified the link between scaffolding and the Vygotskian concept of the Zone of Proximal Development.

\section{REFERENCES}

Bereiter, Carl and Scardamaglia, Marlene (1993): Surpassing Ourselves. Peru: Open Court. Bruffee, Kenneth (1995): Collaborative Learning. Baltimore: Johns Hopkins University Press. Bruner, Jerome (1960): The Process of Education. Cambridge: Harvard University Press.

DAvis, Brent (2004): Inventions of Teaching: A Geneology. Mahwah: Lawrence Earlbaum Associates.

Davis, Brent, Sumara, Dennis and Luce-Kapler, Rebecca (2000): Engaging Minds: Learning and Teaching in a Complex World. London: Lawrence Earlbaum Associates.

Dewey, John (1938): Experience and Education. New York: Simon and Schuster.

Duffy, Thomas M. (2009): Building lines of communication and a research agenda. In: Sigmund ToBias and Thomas Duffy, eds. Constructivist Instruction: Success or Failure. New York/ London: Routledge, 351-367.

ECheverri, Álvaro (2008): Énième plaidoyer pour l'innovation dans les cours pratiques de traduction. Préalables à l'innovation? TTR. 21(1):65-91.

Fenwick, Tara and Tennent, Mark (2004): Understanding Adult Learners. In: Griff Foley, ed. Dimensions of Adult Learning. Sydney: Allen \& Unwin, 55-73.

Hurtado Albir, Amparo (2008): Compétence en traduction et formation par compétences. TTR. 21(1):17-64.

Kiraly, Don (1995): Pathways to Translation. Kent: Kent State University Press.

Kiraly, Don (2000): A Social Constructivist Approach to Translator Education. Manchester: St. Jerome.

Kiraly, Don (2005): Towards Postmodern Translator Education: from Transmission through Construction to Emergence. Meta. 50(4):1098-1111.

KirALY, Don (2006a): Beyond social constructivism: complexity theory and translator education. Translation and Interpreting Studies. 6(1):68-86.

KIraly, Don (2006b): Sprachmittlung in einer komplexen Welt: Die Übersetzerausbildung im Wandel. In: Gerd WотנAк, ed. Quo vadis Translatologie? Ein halbes Jahrhundert universitäre Ausbildung von Dolmetschern und, eds. Übersetzern in Leipzig. Rückschau, Zwischenbilanz und Perspektiven aus der Außensicht. Berlin: Frank und Timme, 191-204.

Kiraly, Don (2008): Transcultural relating: An example of project-oriented translator education. Studia Universitatis Babes-Bolyai - Philologia. (3)5-10.

KIRALY, Don (2009): Acknowledging learning as enaction: moving beyond social constructivism towards empowerment in translator education. In: Colette LAPLACE, Marianne Lederer and Daniel Gile, eds. La Traduction et ses métiers. Caen: Lettres Modernes Minard, 179-191.

KIRALY, Don (2010): Emergence in the language classroom: An experiment in facilitated language acquisition. In: Hannelore LeE-JAHnke and Erich Prunč, eds. Am Schnittpunkt von Philologie und Translationswissenschaft, Festschrift zu Ehren von Martin Forstner. Bern: Peter Lang, 109-119.

Lakoff, George and Johnson, Mark (1980): Metaphors We Live By. Chicago: University of Chicago Press.

Maturana, Humberto R. and Varela, Francisco (1992): The Tree of Knowledge. Boston: Shambhala.

PRECHTER, Robert (2004): The fractal nature of the stock market: the human social experience forms a fractal. In: Nigel Lesmolr-Gordon, ed. The Colours of Infinity: The Beauty, Power and Sense of Fractals. Bath: Clear Press, 128-139. 
Risku, Hanna (1998): Translatorische Kompetenz: Kognitive Grundlagen des Übersetzens als Expertentätigkeit. Studien zur Translation. Vol. 5. Tübingen: Stauffenburg.

Schon, Donald (1987): Educating the Reflective Practitioner. San Francisco: Jossey-Bass.

TudoR, Ian (1992): Learner-centredness in language teaching: finding the right balance. System. 20(1):31-44.

Wood, David, Bruner, Jerome and Ross, Gail (1976): The role of tutoring in problem solving. Journal of Child Psychology and Psychiatry. 17(2):89-100.

Vygotsky, Lev (1994): Extracts from Thought and Language and Mind in Society. In: Barry Stierer and Janet Maybin, eds. Language, Literacy and Learning in Educational Practice. Clevedon: Multilingual Matters, 45-58. 